\title{
A Study of Twenty High School Seniors of Superior Intelligence
}

\author{
Dorothy Hazeltine Yates \\ University of California
}

Purpose and Method of This Study. The aim of this investigation was to study a group of high school seniors of superior intelligence. Various questions suggested themselves, viz.: (I) What kind of homes do these young persons come from? (2) Are their parents or other relatives superior in any respect? (3) Are the young people themselves superior as to health, or were they precocious in physical development? (4) What evidences are there of mental precocity or unusual ability? (5) In what other respects do these superior boys and girls differ mentally from their fellows? It was possible to deal with the first four questions with some degree of thoroughness, but the last called for far too elaborate treatment. However, the matter of interests, especially vocational interests, received some attention.

The Otis group tests (Oakland edition), which are similar to the tests of general intelligence used in our army during the Great War, were given to the five hundred and forty-three high school seniors of Oakland, California, in March, 1919. ${ }^{2}$ The twenty pupils who scored highest, $i$. $e$., less than 4 per cent, were selected for study. For comparison, another group of twenty, whose test scores lay at, or next to, the median score, was chosen. The next step was to make copies of all school records concerning each of the forty. Besides this, as many teachers as possible were asked to give their estimates of each pupil's intelligence and to add any other information they could. Then visits were made to the homes of the twenty superior young persons, where the writer obtained information as to the education, occupation, and achievements of parents and grandparents, the young person's physical development and health, early education, mental development, interests, duties, character, special abilities, and finally, home surroundings, brothers and sisters, special

\footnotetext{
'The writer is indebted to Dr. Virgil E. Dickson, Director of the Oakland Department of Research, for his assistance and advice. Thanks are also due to Professor Warner Brown of the University of California for direction and criticism of this study.
} 
influences, etc. In every case the parents answered most willingly. It should be added that they were almost always reluctant to stress their own children's superiority. The tendency seemed to be to underestimate their ability rather than the reverse. Lastly, a questionnaire dealing primarily with interests was filled out by the forty young persons. This they did in small groups, generally three or four at a time, in the presence of the writer. In some cases she had friendly talks with the pupils in their own homes, but usually the times devoted to the questionnaire furnished the only opportunity for talking with them. They seemed friendly, interested, and anxious to answer the questions carefully.

It must be remembered that one group test does not provide a completely satisfactory way of rating intelligence. Possibly a good many pupils did not do themselves justice. Moreover, we should not clain too much for the tests themselves. Doubtless they fail to give evidence of numerous phases of intellectual superiority. However, the superior pupils selected certainly rank high in the mental abilities that the tests measure.

The Nature of the Two Groups Selected. It is apparent from Table I that the mental-test ratings of the superior group range from 165 (out of a possible 172 points) to 149 . The median for all the seniors was I I8. Eight had precisely this score. To complete what is here called "the median group," twelve pupils whose ratings lay at 117 or 119 were chosen in the chance order in which their names were recorded, rejecting, however, two foreign-born pupils who did not speak English fluently.

Table I shows that there are fourteen boys and only six girls in the superior group. Furthermore, the girls are noticeably below the boys in their standing. ${ }^{2}$ There is only one girl among the seven students at or above 160 , and the rest of the girls fall below 156. Just what this sex difference indicates is not clear. Does it point to the inferiority of the female sex in "general intelligence"? Does it support the theory of greater male variability? Or is it that the Otis tests are better adapted to masculine intellect, training. or temperament, Or are there other factors at work,

${ }^{2}$ Cf. L. M. TERAN, The Intelligence of School Children, N. Y., 1919, pp. 171-172, for somewhat similar findings. The writer has had many suggestions as to the general method of this study from the work of Terman and Margaret Hopwood Hubbard. 
TABLE I. SUPERIOR GROUP

\begin{tabular}{|c|c|c|c|c|c|c|c|}
\hline $\begin{array}{l}\text { Person's } \\
\text { Number }\end{array}$ & $\begin{array}{l}\text { Boy } \\
\text { or QIIrl }\end{array}$ & $\begin{array}{l}\text { Mental- } \\
\text { Test } \\
\text { Rating }\end{array}$ & $\begin{array}{c}\text { Average of } \\
\text { Bigh } \\
\text { School Mlarks }\end{array}$ & $\begin{array}{c}\text { Teachers' } \\
\text { Estimate of } \\
\text { Intelligence }\end{array}$ & Course & $\begin{array}{r}\text { Age at } \\
\text { tion } \\
\text { High }\end{array}$ & $\begin{array}{l}\text { Gradua- } \\
\text { trom } \\
\text { Bcbool }\end{array}$ \\
\hline $\begin{array}{c}1 \\
2 \\
8 \\
4 \\
5 \\
6 \\
7 \\
8 \\
9 \\
10 \\
11 \\
12 \\
18 \\
14 \\
15 \\
16 \\
17 \\
18 \\
19 \\
20\end{array}$ & $\begin{array}{l}\mathbf{B} \\
\mathbf{B} \\
\mathbf{B} \\
\mathbf{B} \\
\mathbf{G} \\
\mathbf{B} \\
\mathbf{B} \\
\mathbf{B} \\
\mathbf{B} \\
\mathbf{G} \\
\mathbf{B} \\
\mathbf{B} \\
\mathbf{G} \\
\mathbf{G} \\
\mathbf{B} \\
\mathbf{B} \\
\mathbf{B} \\
\mathbf{B} \\
\mathbf{G} \\
\mathbf{G}\end{array}$ & $\begin{array}{l}105 \\
162 \\
161 \\
160 \\
160 \\
160 \\
160 \\
168 \\
157 \\
156 \\
165 \\
165 \\
164 \\
158 \\
152 \\
151 \\
151 \\
151 \\
150 \\
149\end{array}$ & $\begin{array}{l}2+ \\
1- \\
1- \\
2 \\
2+ \\
1- \\
2+ \\
3+ \\
2+ \\
2+ \\
2+ \\
2+ \\
1- \\
2+ \\
2+ \\
3 \\
3 \\
2 \\
1- \\
8-\end{array}$ & $\begin{array}{l}1 \\
1 \\
1 \\
1 \\
1 \\
1 \\
1 \\
3 \\
2 \\
1 \\
2 \\
1 \\
1 \\
2 \\
1 \\
3 \\
3 \\
2 \\
1 \\
2\end{array}$ & 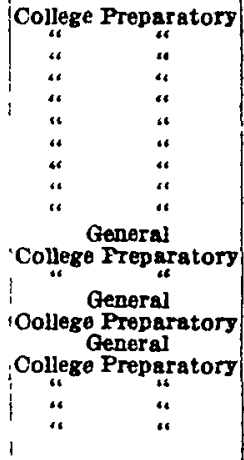 & 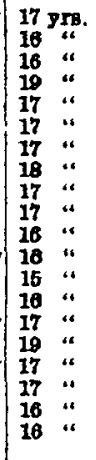 & 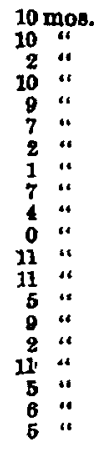 \\
\hline
\end{tabular}

TABLE II. MEDIAN GRODY

\begin{tabular}{|c|c|c|c|c|c|}
\hline Person's Number & Boy or Girl* & $\begin{array}{l}\text { Average } 01 \text { High } \\
\text { School Marks }\end{array}$ & Course & $\begin{array}{l}\text { Age at } \\
\text { trom } \mathrm{E}\end{array}$ & $\begin{array}{l}\text { raduation } \\
\text { b Behool }\end{array}$ \\
\hline $\begin{array}{l}21 \\
22 \\
28 \\
21 \\
25 \\
20 \\
21 \\
29 \\
20 \\
30 \\
31 \\
32\end{array}$ & $\begin{array}{l}\mathbf{B} \\
\mathbf{B} \\
\mathbf{B} \\
\mathbf{B} \\
\mathbf{B} \\
\mathbf{B} \\
\mathbf{B} \\
\mathbf{B} \\
\mathbf{B} \\
\mathbf{B} \\
\mathbf{B} \\
\mathbf{B}\end{array}$ & $\begin{array}{l}2+ \\
2+ \\
\mathbf{2} \\
2 \\
3+ \\
3+ \\
3+ \\
3 \\
3 \\
3 \\
3- \\
3-\end{array}$ & 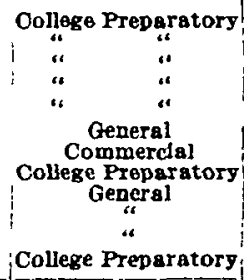 & 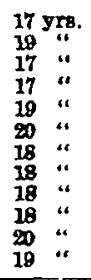 & 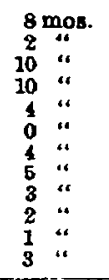 \\
\hline $\begin{array}{l}83 \\
84 \\
35 \\
36 \\
87 \\
38 \\
99 \\
40\end{array}$ & $\begin{array}{l}\mathbf{G} \\
\mathbf{G} \\
\mathbf{G} \\
\mathbf{G} \\
\mathbf{G} \\
\mathbf{G} \\
\mathbf{G} \\
\mathbf{G}\end{array}$ & $\begin{array}{l}1 \\
2+ \\
2+ \\
2 \\
2 \\
2 \\
2+ \\
3+\end{array}$ & $\left\{\begin{array}{c}\text { College Prepsratory } \\
\text { General } \\
\text { Commercial } \\
\text { Oollege Preparatory } \\
\text { General }\end{array}\right.$ & 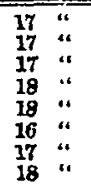 & 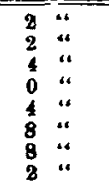 \\
\hline
\end{tabular}

"Slnce the mental-test ratings are practically the same for all (117-119), boys and girls have been grouped separately, beginning with those who have the highest school marks. 
That the boys excel the girls in the mental tests was also apparent for the senior class as a whole, the median for the girls being I I4, for the boys I22. It has been suggested to the writer that the senior boys as a whole might have been superior mentally to the girls, for both inclination and the necessity of going to work would tend to eliminate boys of mediocre intelligence. There were only two-thirds as many senior boys as senior girls. The explanation suggested might well account in part for the boys' superiority. But the writer believes that the chief reason lies in the fact that girls are undoubtedly at a disadvantage in the tests. They suffer from nervousness to a far greater degree than do boys. Their desire to excel becomes "fluster" rather than fruitful effort.

Scholarship and Teachers' Estimates. Comparisons were made of the high school marks with the mental-test ratings and also with the teachers' estimates of intelligence. The school records were not entirely uniform, generally because of the pupil's transfer from another city, but it was possible to accord to each young person an average grade, which. it is believed. is trustworthy. The grades I (excellent), 2 (thoroughly satisfactory), 3 (passed), 4 (failed conditionally), and 5 (complete failure) are used in the Oakland schools. For the sake of finer discriminations plus and minus signs are added in this study.

As many teachers as possible were asked to estimate each superior pupil's intelligence. It was made clear that intelligence, not simply achievement in studies, was to be judged. I is taken to mean "very superior": 2, "superior": 3, "average" : 4, "inferior"; and 5, "very inferior." Such estimates for the median group were not completed.

It will be seen from Tables I and II that fifteen, or 75 per cent, of the superior group have scholarship records at or above 2 , while only Io, or 50 per cent, of the median group are similarly graded. Furthermore, seventeen of the superior pupils took the college preparatory course, which is considered more difficult than other courses; but of the others only eleven took this harder course. It would seem, then, that the superior group tend to do better in school than the median group, though this by no means always follows. The boys of the median group generally range around 3 and never get as high as $\mathrm{I}-$; but the median girls usually do 2 or $2+$ work, one of them even making the highest record (all I's) of all forty. The 
girls of the superior group also generally surpass the boys of that group in school work. As regards estimates of intelligence different teachers did not always agree, but the writer has tried to give representative figures. These (see Table I) are in considerably closer agreement with the Otis-test ratings than are the school marks.

Home Conditions. The home conditions of the superior group were unusually satisfactory. There were no extremes of wealth or poverty, but good, comfortable homes, where the parents were sensible and kindly. The relationship between parent and child, what in the Whittier Scale ${ }^{3}$ is called "parental supervision," was found to be particularly good. Four of the twenty were broken homes, but excellently controlled by intelligent mothers. Two of these were widows. The two others had left their husbands when the sons in question were six and eight years of age respectively.

The young person's place for home study was always noted. In every case but one (number 16 , not a good student and rated low by his teachers) this was found adequate. Number 7 , a remarkably bright boy, did practically no home studying.

Relatives. All the pupils of both groups were born in the United States. It must be remembered, however, that two foreign-born pupils were rejected from the median group because of their ignorance of English. In the superior group, ten, or 50 per cent, were born in California; in the median group. fifteen, or 75 per cent.

The nativity of parents was as follows:

\begin{tabular}{|c|c|c|c|c|}
\hline & & Fathere & Mothers & Both Parents \\
\hline Buperior & $\left\{\begin{array}{l}\text { Native-born } \\
\ldots\end{array}\right.$ & $\begin{array}{r}18 \\
2\end{array}$ & $\begin{array}{l}19 \\
1\end{array}$ & $\begin{array}{r}18 \\
1\end{array}$ \\
\hline Median & $\left\{\begin{array}{lll}\text { Native-born } & \ldots & \ldots \\
\text { Forelga-born } & \ldots & \ldots\end{array}\right\}$ & $\begin{array}{r}14 \\
. \quad 6\end{array}$ & $\begin{array}{r}17 \\
8\end{array}$ & 3 \\
\hline
\end{tabular}

The superior young people, then, were distinctly "American" as to parentage, and somewhat more so than the students whose test rat-

\footnotetext{
"Williams, J. Harold. The Whittier Scale for Grading Home Conditions. Journal of Delinquency, Vol. I, 1916, pp. 273-286.
} 
ings fell at the median. Information as to grandparents is slightly incomplete, because in the case of the median group it was obtained solely from the questionnaire, unverified by the parents. Roughly speaking, for the superior group about 60 per cent of the grandparents were native-born, and for the median group about 45 per cent. For both groups, but more particularly the superior, there was a strong preponderance of Anglo-Saxon stock.

An attempt was made to classify the occupations of parents and grandparents according to Taussig's scale, which has five gradations ranging from the well-to-do, or professional, class to that of daylaborers. Judging social status on this basis, the superior group seemed to rank somewhat higher.

The numbers in the following table show how many parents of the superior pupils completed, or nearly completed, the school course indicated :

\begin{tabular}{|c|c|c|c|c|}
\hline Type of Education & Fathers & Mothers & Total & Both Parents \\
\hline 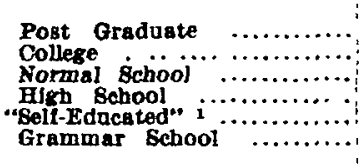 & $\begin{array}{l}1 \\
5 \\
0 \\
8 \\
4 \\
7\end{array}$ & $\begin{array}{l}0 \\
2 \\
\mathbf{2} \\
5 \\
0 \\
6\end{array}$ & $\begin{array}{r}1 \\
7 \\
2 \\
13 \\
13\end{array}$ & $\begin{array}{l}0 \\
2 \\
0 \\
1 \\
0 \\
0\end{array}$ \\
\hline
\end{tabular}

"Self-educated" means with grammar school education supplemented by later study.

Twenty-three, or over one-half, of the parents of the superior boys and girls had a high school or college education. No figures can be given for the median group.

Four of the superior pupils were the only children in their families. In only three of the sixteen remaining families did the mother consider the child in question mentally superior to her other children. In two instances the writer had access to independent data, and these supported the mother's verdict-in the one case, that the child was superior, and in the other, equal in intelligence to the brothers and sisters.

Health and Physical Development. According to their parents, twelve of the superior group were strong in infancy, three had only fair health, and five were sickly babies. In only a few cases had the parents kept records of the child's development, so their statements 
on many points may well be inaccurate. There is little evidence of precocity in getting the first teeth. However, the young people seem, on the whole, to have been precocious in walking and talking. In respect to walking, Mead's statistical study ${ }^{4}$ compares as follows:

\begin{tabular}{|c|c|c|c|}
\hline & Range & Median & Average \\
\hline Mead: 50 normal children ${ }^{*} \ldots \ldots \ldots \ldots \ldots$ & $11-30 \mathrm{mos}$. & $13.54 \mathrm{mos}$ & 11 mos. \\
\hline 'Thls study: 20 superior children & 919 mos. & mos & $122 \mathrm{mos}$. \\
\hline
\end{tabular}

* Since Mead's normal group comprises children of graduate students and a few professors, it is probably rather above average in intelligence.

Since the term "to walk" has been defined more strictly in this investigation than in Mead's, the above figures represent a conservative estimate. An average of the estimated times when the superior children could first use words in short sentences was found to be about nineteen months. Two years is given by most authorities as the usual average. ${ }^{5}$

The list of illnesses, injuries, etc., of the superior boys and girls indicates that they have had their share. However, twelve, or 60 per cent, were judged by their mothers "very superior" to the average in general health, and only two, or 10 per cent, below average (though not seriously so). One of the latter (number 2) had twice undergone operations (appendicitis and stricture) and was subject to colds besides," and the other (number 18 ) was a somewhat delicate boy who suffered from various minor ailments. Except that seven of the group wore glasses, none had any physical defects or deformities. None had ever had any neurotic symptoms, though six were "high-strung," or of a "nervous temperament."

If we accept fourteen to sixteen as the usual age of puberty for boys, the group shows some precocity. We find a range from i 2 to 17 , with an average of 13.7 , and a median and mode at 14 . It is useless to consider only six girls, though a tendency to early physiological maturity also shows with them.

'MEAd, C. D. The Relations of General Intelligence to Certain Mental and Physical Traits. 'Teachers' College, Columbia. Contributions to Education, No. $76,1916$.

"HoL, Ex, Extr. Care and Feeding of Children. N. Y., 1915, p. 35.

'Cf. L M. TERNAN, The Intelligence of School Children, Chapter X, for comparable data in this and the next section. Though Terman's subjects were selected from a greater number and were consequently of a higher mental level, it should be noted that his findings at parallel points are closely similar. 
Education and Mental Development. In all, four, or one-fifth, of the superior pupils went to kindergarten. Only six, or 30 per cent, ever had any formal home teaching. This varied from merely being taught the alphabet (number 12) to regular instruction in spelling, reading, and number work (numbers 13,18 , I9). Table III shows that thirteen of the twenty had learned to read before they went to school. With twelve of them reading was almost wholly a self-initiated and self-conducted process, they "just picked up reading," or "insisted upon being told what the letters and words meant," etc.

After beginning school thirteen children were regular in attending. Table III briefly indicates the attendance record of the remain-

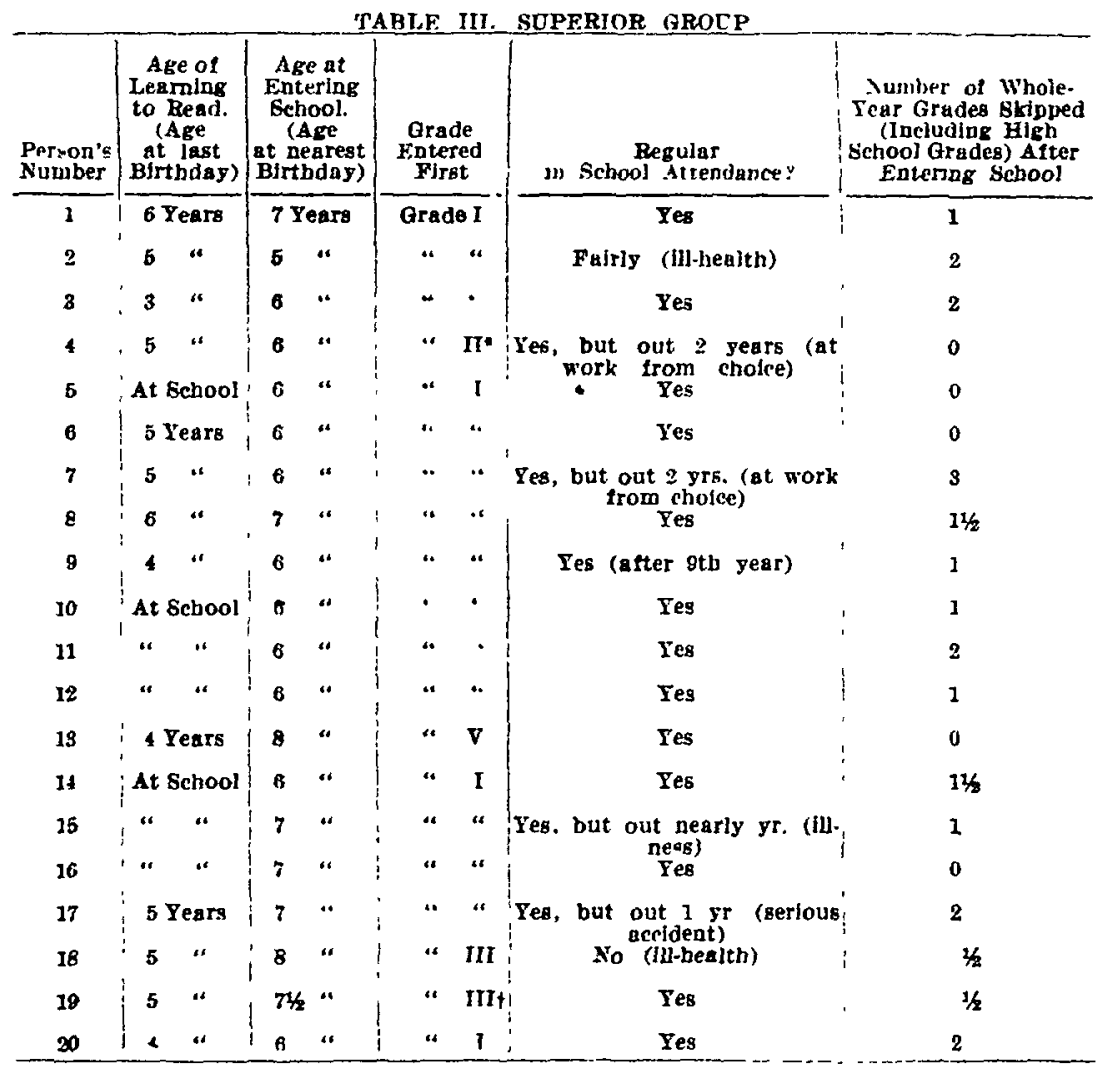

"This sfx-rear-old went into the second grade at once, though his only prerfous means of learning boa been by ifstening to his older sfoter being taught.

toporar 
ing seven. Fifteen, or 75 per cent, skipped from one-half to three whole-year grades (including those of the high school) after entering school; and these figures would be even higher if five of the mothers had not discouraged more rapid progress. Many of the boys and girls took unusually hard high school courses. We have already noted scholarship records in high school (Table I). It is estimated from the parents' judgments and the few available records that sixteen, or 80 per cent, of the group had excellent school marks in the grades previous, and that the four boys who did not acquit themselves so well achieved thoroughly satisfactory marks, nevertheless. Let us compare the ages at graduation from high school of the superior and median groups :

\begin{tabular}{|c|c|c|c|}
\hline & Range & Modian & Average \\
\hline Superior Group & 15.9-19.8 эт8. & $17.6 \mathrm{srs}$. & $17.8 \mathrm{grs}$ \\
\hline Medlan Group & 10.7-20.1 grs. & 18.2 yrs. & $18.8 \mathrm{grs}$. \\
\hline
\end{tabular}

It is clear that the superior pupils were, on the whole, younger than those with a mental rating at the median.

Investigation of each case convinced the writer that there was ample evidence in addition to the tests that at least eighteen of the superior group were distinctly above the average in general intelligence. The other two seemed not remarkable, though there was evidence of their mental alertness. In every case mental ability was found to be general, or "all-round." However, nearly all had some special talent, or talents, such as musical, artistic, literary, or dramatic ability, though none had shown extraordinary gifts.

Interests and Vocational Aims. Space permits only the following more important indications from the questionnaire:

(I) The superior pupils, as a group, did not find their studies easier nor more interesting than did the median group. To a slight extent the reverse was true. Probably this was due to the fact that the college preparatory course, elected by seventeen of the former as against eleven of the latter, offered fewer electives and required subjects that made less popular appeal.

'See Tables I and II. 
(2) In quality the extra-curricular reading of the two groups was much the same. However, difference lay in amount, the average number of hours a week for the superior pupils being 8.9 ; for those of the median group, only 5.I.

(3) The range of "hobbies," or interests, was somewhat greater for the superior young people, both individually and collectively, than for the pupils at the median. The superior group was more interested than the median in activities requiring brain rather than brawn.

(4) In qualities of leadership and organization, and in ability to construct and create, the more intelligent group showed some superiority to the median.

(5) As regards employment (both paid "jobs" and home duties) of the boys, it was found: (a) That employment outside the home had been of much the same nature for both groups. "Paper boy," "delivery boy," "office boy," "ranch hand," "theater usher," "factory helper," "cannery worker," "chauffeur," and "clerk" were typical terms used. (b) But that the superior group had given a little less than half as much time as the median group to outside employment. Since the average number of hours of work a day during times of employment was much the same for both groups. the total amount of employment in years can be compared in the following table :

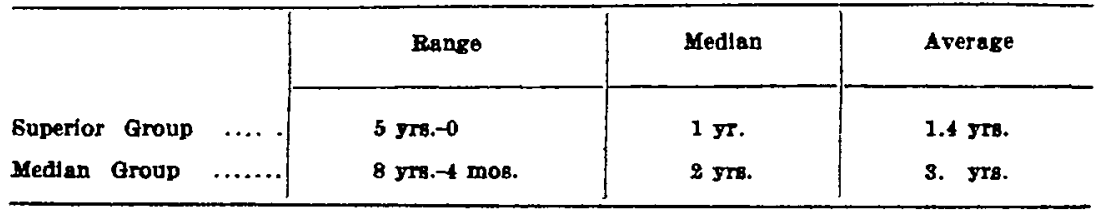

(c) That home duties took the time of both groups about equally.

(6) Regarding employment and home duties of the girls it was discovered: (a) That the amount of paid employment outside the home was insignificant; and that the superior girls had had even less than the girls at the median. (b) The two superior girls $\left(33^{1} / \mathrm{s}\right.$ per cent) who had been employed, listed caring for children and "selling electric lamps"; the four median girls ( 50 per cent) named "clerking" in stores, working in a cafeteria, and working in a fruit cannery. (c) All of the superior group and 62 per cent of the median group had regular home duties.

\footnotetext{
"To get these figures the durations of all the "jobs" of each boy were added.
} 
(7) For neither group, taking into account both boys and girls, was there any clear correlation between past employments and future vocational aims.

(8) The two groups of boys had very similar vocational aims; and the same may be said of the girls. For the former, engineering, chemistry, and law, in the order named, were the most popular fields. The girls expressed a preference for careers as writers and musicians, though commercial work (including stenography), teaching, the stage, and other lines were mentioned.

Conclusions. It should be noted that this paper gives only a very brief summary of some of the facts brought out by the investigation. While no definite conclusions can be drawn with only twenty subjects, this study tends to show that:

I. Mentally superior high school pupils come from homes where conditions are favorable to right development.

2. They are generally precocious physically as well as mentally.

3. They are not below the average in general health.

4. They have less paid employment outside the home than their fellows, and spend more time in reading.

5. They have more intellectual interests, and seem to be somewhat better leaders and organizers than average young people.

6. Pupils of superior and average intelligence have very similar vocational aims.

This study cannot be compared with others of exceptionally intelligent high school pupils, for, as far as the writer knows, there are none that have attempted to get so wide a range of data. There seems to be, however, a growing interest in the "bright" child. We realize that the world needs men with brains. Detailed investigations of the mentality and development of our superior young people will lead, it is hoped, to more adequate educational provisions for them. 